\title{
ANALISIS PENYEBAB ANGKA PUTUS SEKOLAH DAN KONDISI SOSIAL EKONOMI KELUARGA DI KOTA TANGERANG
}

\author{
${ }^{1}$ Dadang Saepuloh \& ${ }^{2}$ Agus Suherman \\ 1, 2 Dosen FKIP Ekonomi Universitas Islam Syekh-Yusuf \\ Email:dsaepuloh@unis.ac.id
}

\begin{abstract}
Abstrak
Penelitian ini bertujuan untuk mengetahui penyebab angka putus sekolah dan kondisi sosial ekonomi keluarga di kota tangerang. Jenis penelitian ini adalah deskripsi kualitatif. Sampel diambil dari Kecamatan Neglasari Desa Kadung Baru dn Kedaung Wetan sebanyak 42 responden yang diobservasi. Hasil penelitian ditemukan bahwa tingkat social ekonomi keluarga dari jenis pekerjaan 1) pekerjaan sebagai pedagang sebanyak $35,7 \%, 2$ ) pekerjaan sebagai pemulung $35,7 \%, 3$ ) pekerjaan sebagai pembantu $14,3 \%$, 4) $11,9 \%$ bekerja sebagai buruh pabrik. Sedangkan dari pendapatan 1) berpenghasilan 1,5 juta-2,5 juta sebanyak $47,6 \%$, 2) 2,5 juta-3,5 juta sebanyak $40,5 \%, 3$ ) sebanyak $11,9 \%$ berpenghasilan berkisar 3,5 juta 4,5 juta. Penyebab angka putus sekolah di Kota Tangerang adalah: 1) Tingginya angka putus sekolah di Kota Tangerang disebabkan oleh ekonomi masyarakat yang lemah, 2) Kurangnya usaha dari orang tua dalam membujuk anaknya dalam melanjutkan penddikan, 3) Kurang meratanya pendataan dari pemerintah setempat dalam merespon program pendidikan sehingga masih banyak orang yang kurang mampu tidak mendapatkan program tersebut.
\end{abstract}

Kata Kunci: Tingkat Sosial Ekonomi Keluarga, Angka Putus Sekolah 


\section{A. Pendahuluan}

Pendidikan memiliki peranan penting dalam meningkatkan sumber daya manusia, karena sejatinya pendidikan merupakan hak asasi setiap warga Negara Indonesia dan untuk itu setiap warga Negara tanpa memandang status social, status ekonomi, suku, etnis, daerah darimana asal seseorang, agama, dan gender, berhak untuk memperoleh pendidikan yang bermutu dan berkualitas sesuai dengan minat dan bakat yang dimiliki. Oleh karena itu, pemerintah harus terus berupaya melaksanakan porgram pemerataan akses pendidikan kepada seluruh masyarakat dengan disertai peningkatan mutu pendidikan diharapkan mendorong terwujudnya pembangunan manusia seutuhnya serta masyarakat madani dan modern yang dijiwai nilai-nilai Pancasila.

Dalam Pembukaan Undang-Undang Dasar (UUD) Negara Republik Indonesia Tahun 1945 menyatakan bahwa salah satu tujuan Negara Kesatuan Republik Indonesia adalah mencerdaskan kehidupan bangsa. Sejalan dengan pembukaan UUD itu, batang tubuh konstitusi tersebut di antaranya Pasal 20, Pasal 21, Pasal 28 C ayat (1), Pasal 31, dan Pasal 32, juga mengamanatkan bahwa pemerintah mengusahakan dan menyelenggarakan satu sistem pendidikan nasional dan memajukan kebudayaan nasional untuk meningkatkan keimanan dan ketakwaan kepada Tuhan Yang Maha Esa serta akhlak mulia dalam rangka mencerdaskan kehidupan bangsa yang diatur dengan undang-undang. Pendidikan anak merupakan bagian yang tidak terpisahkan dari persoalan mencerdaskan bangsa. Melalui pendidikan, anak-anak diasah dengan seperangkat pengetahuan untuk memiliki kesadaran dan kemauan yang positif dalam menemukan dan merumuskan tujuan untuk dirinya di masamasa mendatang. Pembangunan pendidikan di Indonesia telah menunjukan keberhasilan yang cukup besar. Wajib belajar sembilan tahun yang didukung pembangunan insfratruktur sekolah dan diteruskan dengan wajib belajar Sembilan tahun adalah program sektor pendidikan yang diakui cukup sukses. Kasus tinggal kelas, terlambat masuk sekolah dasar, anak putus sekolah dan ketidakmampuan untuk meneruskan sekolah ke jenjang yang lebih tinggi merupakan hal yang cukup banyak menjadi sorotan di dunia pendidikan. (www.cetak.kompas.com, 2009). Dari data Dinas Pendidikan Kota Tangerang melalui Satgas Pendidikan dapat dilihat pada gambar di bawah ini.

$99 \mid$ Pelita - Jurnal Penelitian dan Karya Ilmiah 
Table 1. Angka Putus Sekolah Di Kota Tangerang

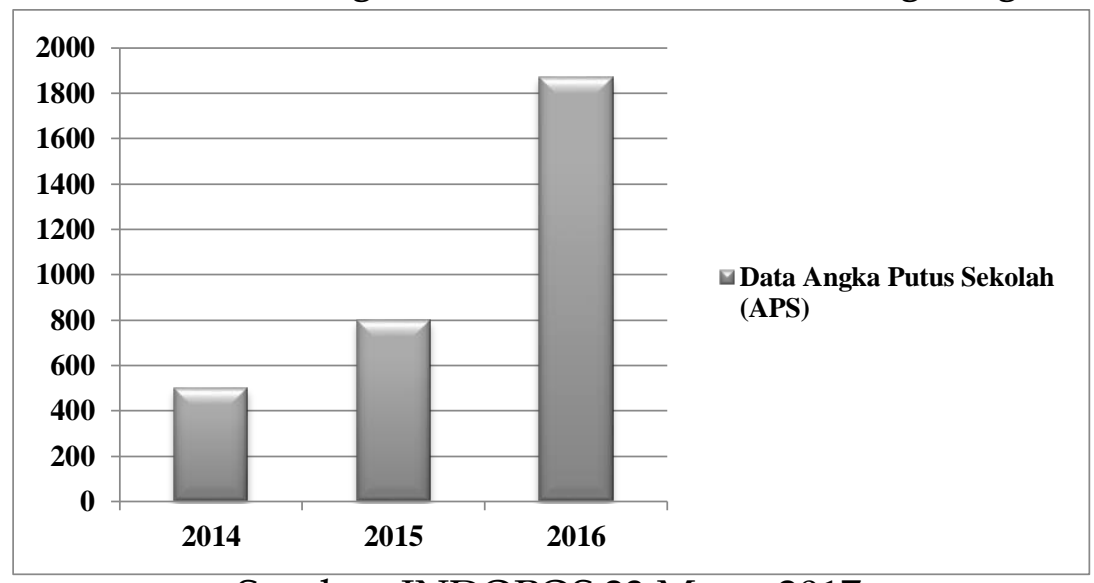

Sumber: INDOPOS 23 Maret 2017

Pada tahun 2014, angka putus sekolah berada pada jumlah 500 anak, sedangkan pada tahun 2015 angka putus sekolah berada pada jumlah 800 anak, bahkan pada tahun 2016 angka putus sekolah meningkat menjadi 1800 anak. Angka putus sekolah pada tahun 2016 mengalami kenaikan bila dibandingkan dengan tahun 2014. Dari angka ini dapat kita lihat bahwa angka putus sekolah dari tahun ke tahun selalu meningkat.

Tabel 2. Indikator Pendidikan Kota Tangerang

\begin{tabular}{|c|c|c|c|}
\hline Uraian & 2013 & 2014 & 2015 \\
\hline Harapan Lama Sekolah (tahun) & 12.6 & 12.86 & 12.9 \\
\hline Rata-rata Lama Sekolah (tahun) & 9.82 & 10.2 & 10.2 \\
\hline \multicolumn{4}{|c|}{ Angka Partisipasi Sekolah (persen) } \\
\hline Usia 7-12 Tahun & 99.57 & 99.6 & 99.43 \\
\hline Usia 13-15 Tahun & 98.24 & 98.21 & 98.48 \\
\hline Usia 16-18 Tahun & 74.95 & 70.17 & 72.99 \\
\hline
\end{tabular}

Sumber: Data Hasil Olah Susenas 2015

Tabel diatas menunjukkan semakin tinggi umur, angka partisipasi sekolah semakin kecil, mengindikasikan bahwa masih banyak penduduk yang tidak dapat melanjutkan ke jenjang pendidikan yang lebih tinggi. Angka Partisipasi Sekolah di Kota Tangerang untuk anak-anak usia 7-12 tahun (usia SD) pada tahun 2015 telah mencapai 99,43 persen. Pada 
kelompok umur 13-15 tahun (usia SLTP) angka partisipasi sekolah lebih kecil (98,48 persen) dan pada kelompok umur 16-18 tahun (usia SLTA) angka partisipasi sekolah hanya sebesar 72,99 persen. Ini berarti bahwa masih ada sebanyak 1,52 persen penduduk usia 13-15 tahun yang tidak melanjutkan pendidikan ke SLTP dan sebanyak 25,49 persen penduduk usia 16-18 tahun yang tidak melanjutkan pendidikan ke SLTA.

Meskipun fakta yang terjadi angka putus sekolah di Kota Tangerang semakin meningkat, sangat tidak sejalan dengan kebijakan pemerintah kota Tangerang yang konsen terhadap pendidikan, seperti halnya kebijakan pendidikan gratis bagi anak usia sekolah melalui program Tangerang Cerdas dan tahun ajaran baru 2017/2018, Pemerintah Kota Tangerang akan menggratiskan biaya sekolah tingkat SD dan SMP baik berstatus negeri maupun swasta. (Wali Kota Tangerang 18 Maret 2017). Muhammad Firman (dalam Ayu Krisna Dewi, 2014), faktor ketidakmampuan membiayai sekolah atau faktor ekonomi menjadi faktor penyebab paling dominan putus sekolah. Kenyataan itu dibuktikan dengan tingginya angka rakyat miskin di Indonesia yang anaknya tidak bersekolah atau putus sekolah berasal dari aspek internalnya, yaitu tidak ada keinginan atau motivasi untuk melanjutkan sekolah dalam diri anak sehingga menyebabkannya memutuskan untuk berhenti sekolah. Selain faktor ekonomi yang mempengaruhi angka putus sekolah ada hal lain yang mempengaruhinya yaitu kurangnya tingkat kesadaran orang tua dan kurangnya pengetahuan tentang pentingnya pendidikan dalam investasi dimasa depan. Seperti halnya yang diungkapkan Robert M. Solow menekankan kepada peranan ilmu pengetahuan dan investasi modal sumber daya manusia dalam memacu pertumbuhan ekonomi. Dad teori Solow ini kemudian dikembangkan teori baru pertumbuhan ekonomi yang dikenal sebagai The New GrowthTheory. H. A. R. Tilaar, dalam (Hastarini Dwi Atmanti: 2005).

\section{Rumusan Masalah}

Berdasarkan uraian pada latar belakang di atas, maka dapat dirumuskan dua permasalahan sebagai berikut:

Apakah kondisi sosial ekonomi keluarga bagian dari penyebab angka putus sekolah di Kota Tangerang? 


\section{Tujuan Penelitian dan Manfaat Penelitian}

1. Tujuan Penelitian

Tujuan dari penelitian ini adalah untuk mengetaui :

a. Kondisi sosial keluarga bagian dari penyebab angka putus sekolah di Kota Tangerang

b. Kondisi ekonomi keluarga bagian dari penyebab angka putus sekolah di Kota Tangerang

2. Manfaat Penelitian

Luaran penelitian ini berupa jurnal publikasi ilmiah yang diterbitkan oleh Lemlit UNIS dan Hasil penelitian ini mempunyai dua manfaat utama, yaitu

a. manfaat teoritis

Diharapkan dapat menambah wawasan pengetahuan dan referensi terkait pembuktian empiris mengenai Kondisi social ekonomi keluarga bagian dari penyebab angka putus sekolah di Kota Tangerang.

b. manfaat praktis

Dapat menjadi masukkan khususnya bagi pemerintah setempat untuk menangani masalah angka putus sekolah sehingga dapat meningkatkan pendidikan di Kota Tangerang.

\section{B. Kajian Teori}

A. Hakekat Tingkat Sosial Ekonomi Keluarga

1. Pengertian Tingkat Sosial Ekonomi

Kalimat status sosial ekonomi berasal dari tiga kata, yaitu status, sosial dan ekonomi.Arti kata status menurut Soerjono adalah tempat atau posisi seseorang dalam suatu kelompok sosial.Adapun menurut Mayor Polak status adalah kedudukan sosial seseorang dalam kelompok serta dalam masyarakat. Sedangkan menurut Dwi Narwoko dan Bagong Suyanto status adalah sebagai tempat atau posisi seseorang dalam suatu kelompok sosial, sehubungan dengan orang lain dala kelompok tersebut, atau tempat suatu kelompok sehubungan dengan kelompok-kelompok lain di dalam kelompok yang lebih besar lagi. Berdasarkan pengertian di atas, dapat disimpulkan bahwa status sosial adalah kondisi atau posisi seseorang dalam suatu kelompok masyarakat.

Adapun pengertian dari sosial berasal dari bahasa Inggris yaitu "society" yang berarti kawan.Seadangkan dalam Kamus Besar Bahasa Indonesia, sosial adalah segala sesuatu mengenai masyarakat dan kemasyarakatan. 
Untuk kata ekonomi, Made Suyasa (2002) menjelaskan bahwa:Istilah ekonomi itu berasal dari bahasa Yunani, yaitu dari kata oikonomia. Oikonomia berasal dari kata oikos dan nomos. Oikos berarti rumah tangga dan nomos berarti tata laksana atau pengaturan.Oikosnomos berarti tata laksana rumah tangga.Perkataan ini mengandung arti tentang hubungan manusia dalam usahanya untu memenuhi kebutuhannya.

Dari uraian diatas maka penulis menyimpulkan bahwa yang dimaksud tingkat sosial ekonomi pada penelitian ini adalah suatu posisi atau status seorang individu dan sebuah keluarga di dalam masyarakat berdasarkan pendapatan, penghasilan, pekerjaan, tingkat pendidikan, jumlah tanggungan yang harus dibiayai dalam satu keluarga, keadaan fasilitas keluarga, dan kondisi pemenuhan kebutuhan pada keluarga tersebut.

Status Sosial Ekonomi adalah peringkat sosial yang didasarkan pada posisi ekonomi yang dicapai serta memiliki karakteristik yang dapat mempengaruhi mobilitas. Untuk menentukan kelas sosial, sosiolog memiliki metode obyektif yang digunakan dalam pengukuran kelas sosial berupa pekerjaan/jabatan dalam organisasi, pendidikan, pendapatan, dan tempat tinggal. Schaefer (Sina, 2005).

\section{Metodologi Penelitian}

A. Tempat Penelitian

Lokasi penelitian dilaksanakan di Kota Tangerang dan melaksanakan observasi di Kecamatan Neglasari Desa Kedaung Baru dan Desa Kedaung Wetan sebagai sampel

B. Metode Penelitian

Metode penelitian ini mengunakan pendekatan studi kasus yang merupakan salah satu jenis dari penelitian kualitatif.

C. Teknik Pengumpulan Data

1. Observasi

Nasution dalam Sugiyono (2012:310), menyatakan bahwa, observasi adalah dasar semua ilmu pengetahuan.Para ilmuan hanya dapat bekerja berdasarkan data, yaitu fakta mengenai dunia kenyataan yang diperoleh melalui obsevasi.Data itu dikumpulkan dan serig dengan bantuan berbagai alat yang sangat canggih, sehingga benda-benda yang sangat kecil (proton dan elektron) ataupun benda yang sangat jauh (benda ruang angkasa) dapat diobservasi dengan jelas. 


\section{Wawancara}

Menurut Esterberg dalam Sugiyono (2012:317), wawancara merupakan pertemuan dua orang untuk bertukar informasi dan ide melalui tanya jawab, sehingga dapat dikontruksikan makna dalam suatu topik tertentu. Dalam penelitian ini penulis menggunakan jenis wawancara semiterstruktur (Semistrutucre Interview) dimana dalam pelaksanaannya lebih bebas bila dibandingkan dengan wawancara terstruktur. Tujuan dari wawancara jenis ini adalah untuk menemukan permasalahan secara lebih terbuka, dimana pihak yang diwawancara diminta pendapat, ide-idenya dan peneliti mendengarkan dengan teliti dan mencatat apa yang dikemukakan oleh informan.

\section{Hasil Penelitian}

A. Kondisi Sosial Ekonomi Keluarga

1. Observasi

Observasi dilakukan pada keluarga yang anggota keluarganya ada yang mengalami putus sekolah. Penulis ingin mengamati kondisi sosial ekonomi keluarganya yang menjadikan salah satu faktor terjadinya angka putus sekolah di Kota Tangerang yang difokuskan di Kecamatan Neglasari tepatnya di kelurahan kedaung wetan dan kedaung baru penulis menggunakan teknik pengumpulan data melalui observasi dan wawancara. Pada observasi, penulis sebagai pengamat / observer. penulis mengamati kegiatan pada keluarga yang anaknya putus sekolah. Hasil pengamatan penulis bisa melihat keadaan kondisi sosial ekonomi keluarga yang putus sekolah.

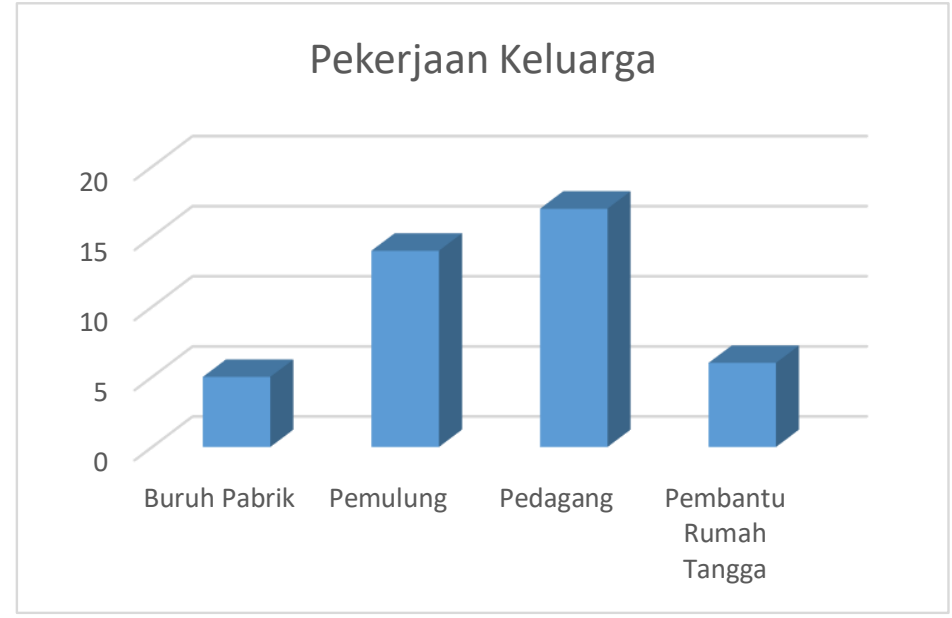

Gambar 1. Sebaran Pekerjaan Kepala Keluarga

$104 \mid$ Pelita - Jurnal Penelitian dan Karya Ilmiah 
Berdasarkan persentase (\%) terhadap 42 responden, bahwa mata pencaharian keluarga anak putus sekolah mencapai 17 responden $(40,5 \%)$ mengatakan bermata pencaharian sebagai pedagang, $(35,7 \%)$ mengatakan bermata pencaharian sebagai pemulung, $(14,3 \%)$ mengatakan bermata pencaharian Pembantu rumah tangga,dan $(11,9 \%)$ mengatakan bermata pencaharian sebagai buruh pabrik.

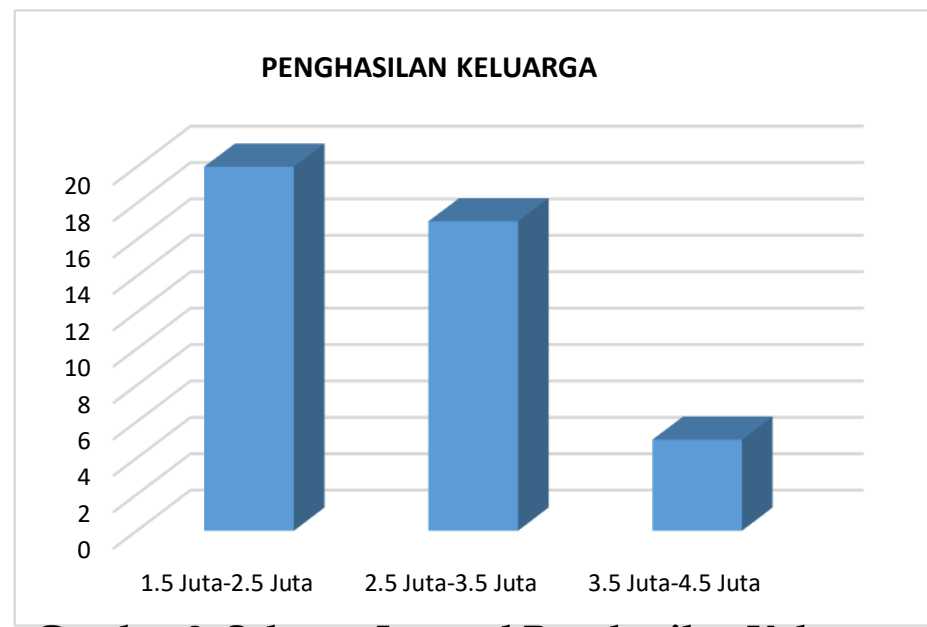

Gambar 2. Sebaran Interval Penghasilan Keluarga

Berdasarkan persentase (\%) terhadap 42 responden, bahwa pengahasilan keluarga anak putus sekolah mencapai 20 responden $(47,6 \%)$ mengatakanberpenghasilan antara 1,5 juta-2,5 juta, (40,5\%) mengatakan berpenghasilan antara 2,5 juta-3,5 juta, dan (11,9\%) mengatakan berpenghasilan antara 1,5 juta-2,5 juta. Sherraden dalam Misno (2014) menyatakan pendapatan adalah semua uang yang masuk dalam sebuah rumah tangga tau unit terkecil lainnya dalam suatu masa tertentu. Ini disebut sebagai arus mengalirnya ( flow) uang. Pendapatan seseorang bisa didapat dari tiga sumber utama: perusahaan, aset, dan santunan (transfer ). Dan Sharraden membagi pendapatan kedalam tiga kelompok yaitu pendapatan tinggi apabila kebutuhan keluarga telah terpenuhi seperti kebutuhan pokok sandang, pangan, papan dan juga terpenuhinya kebutuhan sampingan. Pendapatan sedang apabila kebutuhan keluarga telah terpenuhi kebutuhan pokok saja dan pendapatan rendah apabila kebutuhan belum terpenuhi.

Berdasarkan hasil pengamatan di lapangan menunjukkan bahwa rata-rata angka putus sekolah terjadi karena tingkat sosial ekonomi masyarakat rendah. Dapat dilihat pada gambar diatas menunjukan bahwa 
mata pencaharian dan pendapatan keluarga yang rendah salah satunya menjadi alasan anak putus sekolah.

2. Wawancara

Pengambilan data yang kedua dengan menggunakan instrument wawancara. Wawancara ini digunakan untuk melengkapi data terdahulu yang diambil melalui observasi. Penulis menggunakan data ini sebagai pendukung data sebelumnya. Pada kegiatan wawancara ini Penulis sebagi pewawancara / interviewer. Penulis hanya mewawancarai participant yang menjadi object dalam penelitian ini yaitu 42 keluarga yang anaknya putus sekolah dari Kelurahan Kedaung Wetan dan Kelurahan Kedaung Baru.

\section{a. Responden I}

Berdasarkan hasil wawancara terhadap responden I, dalam anggota keluarganya ada yang putus sekolah yaitu anaknya berhenti dari sekolah ketika kelas 4 SD. Ketika diajukan perntanyaan " apa alas an putus sekolahnya?" orang tuanya mengatakan keterbatasan biaya untuk sekolah tidak tercukupi. Biaya sekolah gratis akan tetapi merasa berat untuk memberikan uang jajan setiap hari dikarenakan tidak cukup untuk memenuhi kebutuhannya sehari-harinya, selain itu anaknya melihat banyak saudara dan temannya yang tidak melanjutkan sekolahnya juga, mereka memilih untuk membantu orang tuanya bekerja sebagai pemulung barang bekas. Ketika ditanya "apakah ibu tahu ada banyak program pemerintah untuk mendukung anak agar tetap sekolah (seperti PKH, KIP, KIS dan Kartu Tangerang Cerdas?" mereka mengaku mengetahui adanya program tersebut ketika ada sosialisai dari sekolah. Berhubung kartunya tidak punya maka tidak dapat bantuan dari program pemerintah, mereka harus mengkonfirmasi kepada RT setempat dan itupun harus mengurusnya menunggu kuota selanjutnya. Dari hasil interview di lapangan menunjukkan bahwa penyebab angka putus sekolah adalah keterbatasan social ekonomi keluarga dan kurangnya sosialisasi dari pemerintah setempat mengenai program-program pemerintah untuk bantuan pendukung pendidikan.

\section{b. Responden II}

Berdasarkan hasil wawancara terhadap responden II, dalam anggota keluarga yang memiliki 3 anak ada yang putus sekolah yaitu anak pertamanya berhenti dari sekolah ketika kelas VII SMP. Dari hasil interview di lapangan menunjukkan bahwa penyebab angka putus sekolah adalah pendapatan keluarga setiap harinya pendapatannya tidak lebih dari Rp. 100.000,00,- karena berprofesi sebagai buruh di pabrik, dengan latar 
belakang orang tua yang seadanya menyebabkan hasil yang didapatkan sehari-harinya hanya bisa untuk memenuhi kebutuhan makan saja, itupun masih terbilang kurang, dengan pendapatan seperti ini membuat penghasilan mereka tidak bisa lagi menpang kebutuhan sekolah anakanaknya secara maksimal. Selain penghasilan yang tidak menetap, jumlah anak yang banyak juga menjadi salah satu dampak dari terjadinya putus sekolah, karena semakin banyak tanggungan anak yang harus di penuhi, tidak semua anak merasakan pendidikan formal. Pendidikan orang tua yang hanya tamat sekolah dasar juga sangat berpengaruh terhadap cara berpikir orang tua untuk menyekolahkan anaknya dan cara pandangan orang tua tentu tidak sejauh dan seluas orang tua yang berpendidikan lebih tinggi. Latar belakang pendidikan orang tua yang rendah merupakan suatu hal yang mempengaruhi anak sehingga menyebabkan anak menjadi putus sekolah dalam usia sekolah. Selain alas an pendapatan dan tingkat pendidikan orang tua juga ada alas an lainnya yaitu banyaknya anak yang putus sekolah didaerah Kedaung wetan ini menyebabkan lingkungan social mereka dipengaruhi oleh teman-temannya Karena anak tersebut berteman dengan anak anak yang tidak bersekolah dan terbawa oleh kebiasaan temannya tersebut seperti nongkrong, dan berkumpul sampai larut malam bahkan sampai dini hari. Dengan terbawa oleh kebiasaan teman yang tidak sekolah akan membuat anak tidak bisa mengikuti pelajaran diskeolah dengan baik karena rasa ngantuk akibat kurang tidur dan juga malas untuk sekolah.

c. Responden III

Berdasarkan hasil wawancara terhadap responden III, dalam anggota keluarga yang memiliki 2 anak ada yang putus sekolah yaitu anak pertamanya berhenti tidak melanjutkan ke tingkat SMA atau sederajat. Dari hasil interview di lapangan menunjukkan bahwa penyebab angka putus sekolah adalah mudahnya akses untuk bekerja menjadi buruh disebuah pabrik sabuk tanpa harus memiliki ijazah, meskipun hanya mendapatkan jagi antara 1 sampai 1,5 juta. Tidak ada usaha dari orang tua untuk membujuk anaknya sekolah, mereka merasa lebih senang anaknya bekerja membantu penghasilan keluarga untuk memenuhi kehidupan sehari-harinya. Pola fikir orang tua yang merasa jika anaknya lulus SMA sederajatpun mereka beranggapan anaknya tetap akan bekerja seperti sekarang, orang tua sudah tidak peduli meskipun ada berbagai program dari pemerintah untuk membantu pendidikan anaknya. Yang paling penting bagi mereka adalah anaknya dapat membantu menambah penghasilan keluarga karena memang bapaknya sebagai kepala rumah 
tangga hanya bekerja menjadi pemulung yang penghasilan perminggunya tidak lebih dari Rp. 500.000,-. Mereka memungut sampah yang biasa dijual setiap hari dan setiap hari minggu di rapikan/di pack untuk dijual kepada pengepul. Berdasarkan dari interview diatas dapat disimpulkan bahwa penyebab angka putus sekolah pada keluarga ini adalah:

1) Adanya akses untuk bekerja di pabrik tanpa ijazah meskipun upahnya tidak layak

2) Paradima yang sama dari orang tua terhadap lulusan tingkat apapun sekolahnnya tetap akan bekerja seperti saat ini

3) Penghasilan keluarga yang masih rendah

d. Responden IV

Berdasarkan hasil wawancara terhadap responden IV, dalam anggota keluarga yang memiliki 3 anak ada yang putus sekolah yaitu anak kedua berhenti tidak melanjutkan dari kelas VIII SMP. Dari hasil interview di lapangan menunjukkan bahwa penyebab angka putus sekolah adalah pengaruh dari teman sebaya, setiap mau berangkat ke sekolah biasa diajak nongkrong bersama teman-temannya di pinggir jalan dengan motif menunggu teman yang belum datang. Pada akhirnya mereka tidak sekolah karena dengan alas an sudah terlalu siang jika berangkat disekolah. Ketika diajukan pertanyaan "apakah orang lain atau orang yang kenal ketika melihat anak-anak sekolah nongkrong mereka menegur?" jawabannya adalah "mereka merasa tidak pernah ditegur sama orang yang melihatnya nongkrong. Ketika dikonfirmasi kepada orang tua mereka merasa menyesal dengan kelakuan anaknya meskipun sudah ditegur dengan berbagai cara baik halus maupun dengan cara kasar. Berdasarkan dari interview diatas dapat disimpulkan bahwa penyebab angka putus sekolah pada keluarga ini adalah:

1) Pengaruh teman sebaya yang mengakibatkan lupa dengan sekolahnnya

2) Kepedulian pemerintah setempat/orang yang melihat mereka nongkrong tidak ditegur atau disuruh untuk berangkat sekolah.

3) Orang tua tidak bisa membujuk dengan cara yang lebih baik agar anaknya peduli dengan sekolah/pendidikan.

e. Responden $\mathrm{V}$

Berdasarkan hasil wawancara terhadap responden $\mathrm{V}$, dalam anggota keluarga yang memiliki 4 anak ada yang putus sekolah yaitu anak kedua berhenti tidak melanjutkan ke jenjang SMA atau sederajat. Dari hasil interview di lapangan menunjukkan bahwa penyebab angka putus sekolah 
adalah keterbatasan dalam biaya untuk uang jajan sehari-hari dan membeli buku tulis serta buku pelajaran, meskipun mereka tahu ada berbagai program pemerintah yang bisa mendukung pendidikan. Tapi keluarga ini merasa tidak diberikan program tersebut oleh pemerintah setempat/ RT, terkesan dibeda-bedakan dengan faktor saudara dan kedekatan denganRT padahal orang tuanya hanya bekerja sebagai pemulung yang penghasilannya tidak menentu dan masih kurang untuk memenuhi kebutuhan sehari-hari. Meskipun anak pertamanya bisa melanjutkan ke perguruan tinggi dengan biaya sendiri, ketika SMP dan SMA melalui jalur paket serta bisa melanjutkan ke perguruan tinggi. Kakaknya setiap hari memotivasi agar bisa mengikuti jejak kakaknya meskipun sekarang sudah tidak sekolah lagi. Berdasarkan dari interview diatas dapat disimpulkan bahwa penyebab angka putus sekolah pada keluarga ini adalah: Keterbatasan biaya yaitu kurang meratanya pembagian program pemerintah seperti TangCer, KIP, PKH, KIS dan lain-lain. Karena program ini bisa didapatkan dengan rekomendasi dari RT setempat pada awal pendaftaran

\section{E. Penutup}

1. Kesimpulan

Berdasarkan hasil penelitian melalui observasi dan interview yang telah dilaksanakan di Kecamatan Neglasari Kota Tangerang Penulis menyimpulkan hasil penelitian berdasarkan tujuan penelitian ini, sebagai berikut:

1. Tingginya angka putus sekolah di Kota Tangerang disebabkan oleh ekonomi masyarakat yang lemah

2. Kurangnya usaha dari orang tua dalam membujuk anaknya dalam melanjutkan penddikan

3. Kurang meratanya pendataan dari pemerintah setempat dalam merespon program pendidikan sehingga masih banyak orang yang kurang mampu tidak mendapatkan program tersebut. 


\section{Saran}

Terjadinya angka putus sekolah disebabkan oleh kurang mampunya masyarakat secara ekonomi, maka pemerintah harus hadir dalam mengatasinya diantaranya adalah:

1. Pemerintah mengadakan sosialisai secara terus menerus akan pentingnya pendidikan terhadap masa depan agar masyarakt merubah pola pikir

2. Pemerintah harus dengan adil menjalankan programnya terutama harus melakukan monitoring langsung kepada masyarakat agar program tepat sasaran

3. Pemerintah harus sering mengadakan acara yang berkaitan dengan pendidikan agar mampu meningkatkan kepedulian masyarakat terhadap pendidikan.

\section{Referensi}

Arikunto, S. (2006). Prosedur penelitian suatu pendekatan praktik, Jakarta: PT Rineka Cipta.

Alijoyo, A., \& Zaini, S. (2004). Komisaris independen penggerak praktik GCG di perusahaan. Jakarta : PT. Indeks 51,58.

Aristin, N. F. (2015). Faktor- Faktor yang Berpengaruh terhadap Anak Putus Sekolah Tingkat Sekolah Menengah Pertama (SMP) di Kecamatan Bondowoso. Jurnal Pendidikan Geografi. TH. 20, No.1, jan 2015.

Atmanti, H. D. (2005). Investasi Sumber Daya Manusia melalui Pendidikan. Vol. 2 No. 1 / luli 2005: 30 - 39.

Badan Pusat Statistik Kota Tangerang. (2016), Katalog BPS : 1101002.3671

Badan Pusat Statistik Kota Tangerang, Statistik Daerah Kecamatan Neglasari. (2016). Katalog BPS : 1101002.3671.

Depdiknas Republika Indonesia. (2003). Undang-undang Republika Indonesia Nomor 20 tentang Sistem Pendidikan Nasional, Jakarta 1 .

Djaali., \& Muljono, P. (2008). Pengukuran dalam Bidang Pendidikan, Jakarta: Grasindo 3.

Kartono, K. (1997). Patologi Sosial Jilid 5, Jakarta: PT.Raja Grafindo Persada.

Dwi, N., \& Bambang, S. (2004). Sosiologi Teks Pengantar dan terapan. Jakarta: Prenada Media, Edisi Pertama.

Narmoko, S. (2004). Sosiologi Teks Pengantar dan Terapan. Jakarta: Prenada Media.

110|Pelita - Jurnal Penelitian dan Karya Ilmiah 
Suyasa, M. (2002). Ekonomi dan Koprasi. Bandung: Rosada Karya .

Sandjaja. (2002). Pengaruh Keterlibatan Orang Tua Terhadap Minat Membaca Anak Ditinjau dari Pendekatan Stres Lingkungan, Jakarta: Jurnal Ilmu-Ilmu Sosial.

Sugiyono. (2007). Metode Penelitian Pendidikan pendekatan Kualiitatif, Kuantitatif dan $R \mathcal{E} D$. Bandung: Alfa Beta.

Suharsimi, A. (2003). Dasar-dasar Evaluasi Pendidikan. Yogyakarta : Bumi Aksara

Sandjaja, S. (2002). Pengaruh Keterlibatan Orang Tua terhadap Minat Membaca Anak Ditinjau dari Pendekatan Stres Lingkungan Jakarta. Jurnal Ilmu-Ilmu Sosial. No. 3.

Sumber Web. http://megapolitan.indopos.co.id/read/2017/03/23/ 92189/1870-Anak-Anak-PutusSekolah-di-Kota-Tangerang http://kabar7.com/detail/tahun-ajaran-baru-kota-tangeranggratiskan-sd-dansmp/18443/2017-03-18\#sthash.CU2863kD.dpuf. 